実験肝炎モデルマウスにおける細胞性免疫の検討

一肝組織内浸潤リンパ球の T-cell subpopulation について一

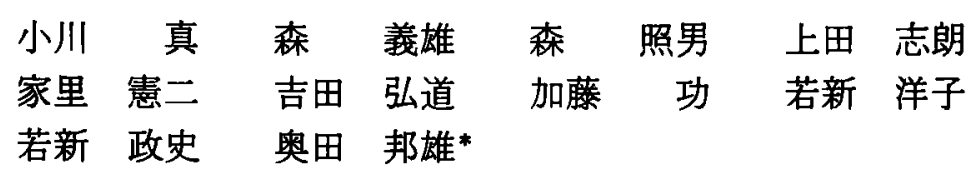

要 旨：近交系 C57BL/6 (B6) マウスに，同采肝抗原を免疫することにより作製した実駼肝资 モデルマウスより, 脾細胞, 末梢血単核細胞, 肝内浸潤細胞を単離し，末梢血単核細胞及び脾 細胞の肝細胞膜特異抗原（LSP）に対する反応性を調べた。更にこれら単核細胞中の T 細胞の 比率, 特に Ly 1, Ly 23, Ly 123の subpopulation の検索を到 Cr-release 法による cytolytic test により行なった。

その結果，末梢血単核細胞及び脾細胞中の T細胞が LSP に対して反応性を示した。また肝内 浸潤細胞では T cell が32.7\%を占め，この5ち，Ly 23 細胞 (cytotoxic/suppressor) は約 $40 \%$ であった。.また䖝光抗体法及び醅素抗体法による染色では，肝組織の門脈域を中心として Ly 23 陽性細胞がみられ, killer 細胞の肝内浸潤と考えられたが, 一方 Ly 1 陽性細胞も認められ, こ れらの細胞相互作用の検索が必要と思われた。

索引用語： 近交系 C57BL/6（B6） マウス 実験的肝炎 肝内浸潤細胞

T-cell subpopulation T-cell mediated cytotoxicity

\section{緒 言}

肝炎の発症及び進展の過程において免废学的機序の 関与していることはよく知られており，なかです細胞 性免㳟機構が重要な役割を果たしていることが,種々 の in vitroの assay 系の检討1.22 から推測されている。

しかしながら，実際に肝細胞を障害する，effector cell についてはいまだに不明な点が多く，この機序を 解明するためには, 肝組織内へ浸潤した紐胞の検索が 必要となってくる.

以前より浸潤リン八球と肝細胞が接触する interaction の像かみられることが指摘》され、リンバ球によ る細胞障害性が注目されてきたが，最近種々の肝疾患 飞和いて monoclonal 抗体を用いた肝内浸潤細胞 subpopulationの検討が行なわれ, 肝障害の場におけ るリンパ球の動態及び細胞間相互作用につき検索が進 みつつある。

著者らは近交系 C57BL/6 (B6) マウスに同系マウス

-千葉大学第 1 内科

<受付日60年 7 月 22 日 $>$
の肝抗原を免疫することにより，実験肝炎モデルの作 製に成功しタ)，さらに感作リンバ球 transfer による肝 障害の発症 ${ }^{9 !}$, in vitro の細胞障害試験の検討 ${ }^{10)}$ などか ら,このモデルにおいて細胞性免疫機構の果たす役割 について検討を加えてきた。

今回, 肝炎マウスの末梢血単核細胞, 脾細胞及び肝 内浸潤細胞を単離し, T-cell subpopulation について 検討を加えたので報告する.

\section{材料及ひ方法}

\section{1. 動物及 U゚肝障害の作裴}

近交系 C57BL/6 (B6) マウスから得た新鮮な肝を等 量の生理食塩水と共にホモジナイズし, $100,000 \mathrm{~g} て ゙ 1$ 時間遠心後，上清を得てこれを肝抗原とした， $0.1 \mathrm{~m} l$ の肝抗原を等量の Freund's complete adjuvant 之共 に同系マウス背筋に 4 6 回毎週 1 回の頻度で免疫 し, 最終免疫 7 日後に sacrifice し, 肝, 脾及び末梢血 を無菌的に採取. 肝の一部の組織学的及び免疫組織化 学的検索を行ならと共に, 各々より単核細胞を分離し, 細胞性免疫的検索を行なった。各種検索は 1 回に 5 匹 のマウスに対して行ない, 計 5 回くり返した。 


\section{2. 組戥学的検索}

最終免疫 7 日後に得た肝の組織切片をへマトキシリ ンニエオシンにて染色し，肝組織像の検討を行なった。

3. 単核細胞の分離・分画

末梢血：心葴穿刺によりへハリン採血した末梢血よ ク，Ficoll-Paque を用いた密度勾配分離法により単核 細胞を得た。

脾細胞：無菌的に採取した軒を，金属 mesh（\#200） を通過させて分離脾細胞を得た。

肝浸潤単核細胞：無菌的に取り出した肝を2 $5 \mathrm{~mm}$ の細片に切り, rough mesh, ガーゼ, \#200金属 mesh を 用いて細胞浮遊液を得, Ficoll-Paque 密度勾配分離法 により，単核細胞層を採取した。単核細胞はすべて 7.5\%fetal calf serum (FCS)を含んだ RPMI （GIBCO）に浮遊させさらに脾細胞及び肝内浸潤細胞 については, nylon wool column (NWC) を用いて NWC non-adherent (T-enriched) 及び NWC adherent（B cell，macrophage を含む）に分け，分画前の ものと比較した。

\section{Lymphocyte transformation test}

肝炎マウス及び正常 B6マウスより得た，末梢血単核 細胞及び脾細胞の，同系 LSP に対する反応性を， ${ }^{3} \mathrm{H}$ thymidine uptakeによる lymphocyte transformation test を用いて検索した。

LSP は MacFarlane らの方法 ${ }^{11}$ に準じて精製し Hanks' balanced salt solution にて一晚透析し, EDTA の影響を除いた. 添加濃度は非特異的反応のみ られない $12.5 \mu \mathrm{g} / \mathrm{m} l$ 以下を用いた。

末梢血単核細胞及び脾細胞各分画を $1 \times 10^{5} /$ well す つ microtest plate（Nunc）に分注L，LSP 添加後， 10\% FCS を含んだ，RPMI 1640 buffer 下にて, $37^{\circ} \mathrm{C}$ $\mathrm{CO}_{2}$ incubator 内で 4 日間培養 し, $0.1 \mu \mathrm{Ci}{ }^{3} \mathrm{H}$ thymidine を加光，16時間後にハーベストして ${ }^{3} \mathrm{H}$ thymidine uptake count した.

\section{5. 単核細胞中の T-cell の比率の検定}

各単核細胞におけるT-cellの比率の検定を antiThy 1,2 monoclonal 抗体及び補体を用いた cytolytic testによって行なった，Thy 1,2 はマウス胸腺細胞及 び末梢リンバ組織中の胸腺由来細胞にみられる分化抗

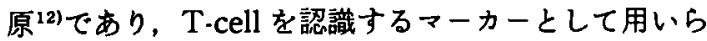
れている。

単核細胞各分画 $1 \times 10^{7} / \mathrm{m} l$ に対し， $200 \mu \mathrm{Ci}$ の割合で $\mathrm{Na}_{2}{ }^{51} \mathrm{CrO}_{4}$ を加え， $37^{\circ} \mathrm{C} 5 \% \mathrm{CO}_{2}$ の条件下で 1 時間標識 する. 洗浄後，1\%FCS を加えた Dulbecco's Modified
Eagle Medium (GIBCO) に浮遊させ microtest plate に1×105/well ずつ入れ, anti-Thy 1, 2 monoclonal 抗 体 (Olac) 及び rabbit 補体を作用させた。対照として は saponin 溶液を最終濃度1.0\%となるよ5に加えた

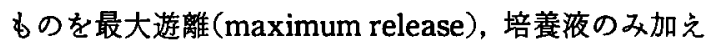
たものを自然遊離（spontaneous release）とし，反応 後 $1,200 \mathrm{rpm}$ で 7 分間遠心し，培盖上清中 ${ }^{51} \mathrm{Cr}$ release を測定し以下の式にて\%reduction 值を算出 し, T-cell の比率とした。

$\%$ reduction $=$ cpm by experiment $\frac{- \text { cpm by spontaneous release }}{\text { cpm by maximum release }} \times 100$

\section{T-cell subpopulation $の$ 検索}

Cantor らの方法 ${ }^{13}$ に準じ, anti-Ly 1, anti-Ly 2抗体 及び補体（C）を用いて，各単核細胞分画の $\mathrm{T}$ cell subpopulation を検定した。 Ly 抗原系はマウス T-cell の特異的分化抗原であり，この組み合わせにより Tcell は, Ly 1, Ly 23, Ly 123の 3 種に亜分類される.

各単核細胞を $\mathrm{Na}_{2}{ }^{51} \mathrm{CrO}_{4}$ を用いて標識した後，antiLy 1 まは anti-Ly 2抗体（抗 mouse rat IgG-Fab) を作用させ，第 2 抗体として抗 rat $x$-light chain mouse 抗体を作用させた後, rabbit complement 兄，反応釉了後の培養上清中の ${ }^{51} \mathrm{Cr}$ を測定した。 それ ぞれ\%reduction 值を求めた上で, Ly 1, Ly 23, Ly 123 の各単核細胞に対する比率を以下の式で算出した。

$\mathrm{T}:$ Ratio of Thy $1^{+}$cells

$=\%$ reduction by anti-Thy $1,2+\mathrm{C}$

A : Ratio of Ly 1 $=\mathrm{T}-(\%$ reduction by anti $-\mathrm{Ly} 2+\mathrm{C})$

B : Ratio of Ly 23 $=\mathrm{T}-(\%$ reduction by anti-Ly $\mathrm{I}+\mathrm{C})$

C: Ratio of Ly $123=\mathrm{T}-(\mathrm{A}+\mathrm{B})$

Thy $1^{+}$cell (T-cell) に対する比率は A, B, CをT で除して算出した。

\section{7. 免疫組織化学的検索}

間接螢光抗体法及び酔素抗体法により浸潤 T細胞 subpopulation 別分布傾向の検討を試みた，螢光抗体 法は最終免疫 7 日後に sacrifice した肝资マウス肝よ り涷結切片標本を作製し， anti-Ly 1及び anti-Ly 2 rat 抗体を第 1 抗体，anti-rat $\gamma$-globulin-FITC を第 2 抗 体として用いた。酵素抗体法は同時に作製した組織標 本 (H-E 染色) に xylene, ethanol 等を用いて脱パラ フィン処置を行なった上で，anti-Ly 1及び anti-Ly 2 
抗体, peroxidase conjugated anti-rat IgG 抗体を順 次作用させ, DAB- $\mathrm{H}_{2} \mathrm{O}_{2}$ (DAB：3，3' diaminobenzidine-4HCl）にて発色させた後, 脱水後包埋した.

$$
\text { 結 果 }
$$

\section{1. 組織学的検索}

肝抗原及びアジェバントを毎週 1 回, 合計 6 回免疫 し, 最終兔疫 7 日後にマウスを sacrifice し, 肝組織像 の検索を行なった. Fig. 1に示すように, 門脈域を中心 とした. 中程度から強度の単核細胞の漫潤が認められ， 一部には肝細胞壊死す認められた。

\section{Lymphocyte transformation test}

肝炎マウス及び正常マウスの末梢血単核細胞及び脾 細胞各分画につき, syngeneic な LSP に対する反応性



Fig. 1 Liver specimen of C57BL/6 (B6) mouse immunized six times with liver antigens. Moderate to severe mononuclear cell infiltration is seen.

Table 1 In vitro ${ }^{3} \mathrm{H}$-thymidine uptake by mononuclear cells from C57BL

(B6) mice immunized with liver antigen after stimulation by LSP.

\begin{tabular}{|c|c|c|c|}
\hline \multirow{2}{*}{ Fraction of mononuclear cells } & \multicolumn{3}{|c|}{ LSP concentration $(\mu \mathrm{g} / \mathrm{ml})$} \\
\hline & 12.5 & 6.25 & Control \\
\hline $\begin{array}{l}\text { 1. Lymphocytes in } \\
\text { peripheral blood }\end{array}$ & $1864 \pm 1104^{* *}$ & $824 \pm 44^{*}$ & $656 \pm 96$ \\
\hline $\begin{array}{l}\text { 2. Spleen cells } \\
\text { Unfractionated cells }\end{array}$ & $3618 \pm 585^{*}$ & $2332 \pm 1399$ & $2350 \pm 685$ \\
\hline $\begin{array}{l}\text { Nylon wool column } \\
\text { non-adherent cells }\end{array}$ & $3963 \pm 2341^{* * *}$ & $3016 \pm 1560$ & $1534 \pm 376$ \\
\hline $\begin{array}{l}\text { Nylon wool column adherent } \\
\text { cells }\end{array}$ & $2794 \pm 1067^{*}$ & $1899 \pm 650$ & $1570 \pm 480$ \\
\hline
\end{tabular}

Control : incorporation of ${ }^{3} \mathrm{H}$-thymidine by mononuclear cells cultured without LSP.

Degree of significance in comparison with control :

"p<0.05, *p $<0.01, \quad * * p<0.001$.

Table 2 Ratio of T-cell population in normal and immunized C57BL/6 (B6) mice checked by ${ }^{51} \mathrm{Cr}$-release assay using anty-Thy 1,2 antibody and complement.

\begin{tabular}{l|c|c}
\hline \multicolumn{1}{c|}{$\begin{array}{c}\text { Fraction of } \\
\text { mononuclear cells }\end{array}$} & $\begin{array}{c}\text { B6 mice immunized with } \\
\text { liver antigens }\end{array}$ & $\begin{array}{c}\text { Control } \\
\text { (normal B6 mice) }\end{array}$ \\
\hline 1 Lymphocytes in \\
$\begin{array}{c}\text { peripheral blood } \\
\text { Spleen cells } \\
\text { Unfractionated cells } \\
\text { Nylon wool column } \\
\text { non-adherent cells }\end{array}$ & $58.3 \pm 6.7 \%$ & $45.2 \pm 5.9 \%$ \\
$\begin{array}{l}\text { Nylon wool colmn } \\
\text { adherent cells }\end{array}$ & $37.5 \pm 5.5$ & $31.8 \pm 3.2$ \\
\hline 3 Infiltrating mononuclear cells in liver \\
$\begin{array}{l}\text { Unfractionated cells } \\
\text { Nylon wool column } \\
\text { non-adherent cells }\end{array}$ & $32.7 \pm 5.5$ & $70.3 \pm 4.3$ \\
$\begin{array}{l}\text { Nylon wool column } \\
\text { adherent cells }\end{array}$ & $53.7 \pm 10.8$ & $26.9 \pm 3.8$ \\
\hline
\end{tabular}

-Significantly different $(p<0.01)$ from control. 
を, ${ }^{3} \mathrm{H}$-thymidine uptake を用いた lymphocyte transformation testにて検索した (Table 1).

添加 LSP 瀑度 $12.5 \mu \mathrm{g} / \mathrm{m} l$ に打いて，末梢血単核細 胞及び, 脾細胞 NWC non-adherent 分画(T-enriched) で強い陽性の反応を示している. 脾細胞 NWC adherent 分画や，分画前脾細胞での反応は，非常に mild で あった。

\section{T-cell の比率の検定}

anti-Thy 1,2, monoclonal 抗体を用いて, 各単核細 胞中に占める T-cell の比率を検定した結果を Table 2 に示す。
末梢血は心臟穿刺により得たが，その白血球数は肝 炎マウスでやや多い傾向がみられたすのの有意差はみ られなかった（肝炎マウス $10,760 \pm 1,396 / \mathrm{mm}^{3}$, 正常 マウス $8,320 \pm 688, \mathrm{n}=10$ ) 分画す肝炎マウスで好中球 その他顆粒球系70\%,リンハ球 $24 \%$, monocyte ないし 大リンバ球 $6 \%$ で正常マウスと活济同様であった。 こ れをく材料及び方法〉で示したように Ficoll-Paque を用いて分離したところ，顆粒球系20\%，リンパ球 $65 \%$, monocyte ないし大リン八球15\%の分布となっ た.この分離細胞を検索すると，肝炎マウスでやや Tcell が多い傾向がみられたが，有意差はなかった。

Table 3 T-cell subpopulation in normal and immunized C57B1/6 (B6) mice checked by ${ }^{51} \mathrm{Cr}$-release assay using anti-Ly specific antibodies and complement.

\begin{tabular}{|c|c|c|c|c|}
\hline & \multicolumn{2}{|c|}{ Hepatitis B6 mice } & \multicolumn{2}{|c|}{ Normal B6 mice } \\
\hline & $\begin{array}{l}\text { for total } \\
\text { cells }(\%)\end{array}$ & $\begin{array}{l}\text { for Thy } 1+ \\
\text { cells }(\%)\end{array}$ & $\begin{array}{l}\text { for total } \\
\text { cells }(\%)\end{array}$ & $\begin{array}{l}\text { for Thy } 1+ \\
\text { cells }(\%)\end{array}$ \\
\hline \multicolumn{5}{|c|}{ Peripheral blood lymphocytes } \\
\hline Ly 1 & $16.6^{*}$ & $28.3^{*}$ & 1.7 & 3.8 \\
\hline Ly 23 & $14.4^{*}$ & $24.9^{*}$ & 1.7 & 3.8 \\
\hline Ly 123 & 27.3 & 46.9 & 41.8 & 92.8 \\
\hline \multicolumn{5}{|c|}{$\begin{array}{l}\text { Spleen cells } \\
\text { Unfractionated cells }\end{array}$} \\
\hline Ly 1 & 13.6 & 36.3 & 12.9 & 46.4 \\
\hline Ly 23 & $7.9^{*}$ & $21.1^{*}$ & 2.7 & 8.4 \\
\hline Ly 123 & 16.0 & 42.6 & 16.2 & 50.9 \\
\hline \multicolumn{5}{|c|}{ Nylon wool column non-adherent cells } \\
\hline Ly 1 & $27.1^{*}$ & $40.0^{*}$ & 38.6 & 54.9 \\
\hline Ly 23 & 12.8 & 18.9 & 13.5 & 19.2 \\
\hline Ly 123 & $28.0^{*}$ & $41.1^{*}$ & 18.2 & 25.9 \\
\hline \multicolumn{5}{|c|}{ Nylon wool column adherent cells } \\
\hline Ly 1 & 9.6 & 20.8 & 11.2 & 41.6 \\
\hline Ly 23 & $6.4^{*}$ & $13.9^{*}$ & 1.4 & 5.2 \\
\hline Ly 123 & $30.2^{*}$ & $65.3^{*}$ & 14.3 & 53.2 \\
\hline
\end{tabular}

Infiltrating mononuclear cells in liver Unfractionated cells

\begin{tabular}{l|r|r|} 
Ly 1 & 17.1 & 52.3 \\
Ly 23 & 12.9 & 39.4 \\
Ly 123 & 2.7 & 8.2 \\
\hline
\end{tabular}

Nylon wool column non-adherent cells \begin{tabular}{l|l|l} 
Ly 1 & 27.4 & 51.0
\end{tabular} \begin{tabular}{l|l|l} 
Ly 23 & 20.0 & 37.2
\end{tabular} Ly 123 6.3 11.8

Nylon wool column adherent cells

\begin{tabular}{l|c|c|} 
Ly 1 & 20.6 & 57.9 \\
Ly 23 & 15.0 & 42.1 \\
Ly 123 & 0 & 0
\end{tabular}

-Significantly different $(p<0.01)$ from normal B6 mice 
脾細胞については，分画前及び NWC non-adherent 分画では対照との差がみられなかったが，NWC adherent 分画において肝炎マウスで有意に T.cell の比 率が高かった。

肝炎マウス肝よりは，肝実質細胞の涅入のない， $2 \sim 5 \times 10^{7} /$ Mouse の単核細胞が得られ May-Giemsa 染色では70\%以上をリンパ球が占めた. 正常 B6マウス 肝よりは同じ手法を用いてもほとんど細胞が得られな いため，肝炎マウス肝より得た単核細胞はほぽすべて

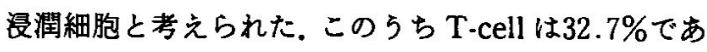
$\eta, \mathrm{NWC}$ non-adherent 分画の54\%, NWC adherent の36\%が T cell であった。

\section{4. $T$ cell subpopulation $の$ 検索}

anti-Ly 1 及び anti-Ly 2 抗体を用いて検索した T. cell subpopulation ( $\mathrm{Ly}$ 抗原系) の結果を Table 3 に 示す.

末梢血単核細胞では，肝炎マウスにおいて Ly 1, Ly 23 と著明な增加を示している。

脾細胞では分画前及び NWC adherent 分画におい てLy 23が増加しており，その他にも種々の点で正常 マウスとの相違がみられた。

肝内浸潤 T-cell 中, 約50\%が Ly 1, 約 $40 \%$ が Ly 23 であり, NWC non-adherent 分画中の $37 \%, \mathrm{NWC}$ adherent 分画の $42 \%$ Ly 23 が占めた。 これら肝内浸 潤紏胞中の Ly 23の比率は脾細胞各分画よりも高い㑯 向があった.

\section{5. 免疫組織化学的検索}

溃光抗体法及び酵素抗体法に上り漫潤細胞 T-cell subpopulationを検索したところ，門脈域及び肝実質 内にて Ly 2陽性細胞が認められた (Fig. 2a, Fig. 2b). Ly 1陽性細胞も相当な比率で認められたが，両者の間 に明らかな分布の差はみられなかった。部位及び個体 差がかなりあるため，分布㑯向の観察にとどめ，数量 的解析は行なわなかった。

\section{考察}

免疫学的機序に基つく実験肝炎モデル作製及びその 解析の報告は比較的少ない。

1972年, Meyer zum Büschenfelde らはヒト LSP 及 びアシュバンドを rabbitに長期免疫することにより，

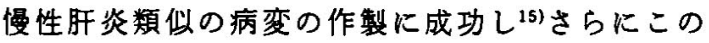
rabbit 血清中に抗 LSP 抗体の存在を証明し ${ }^{16)}$, 液性免 疫機序の関与を推測した。種々の肝疾患患者にも LSP に対する自己抗体が検出され ${ }^{17}$ ，抗 LSP 抗体を主体と する抗肝細胞膜抗体の意義が, 肝疾患で重視されてき

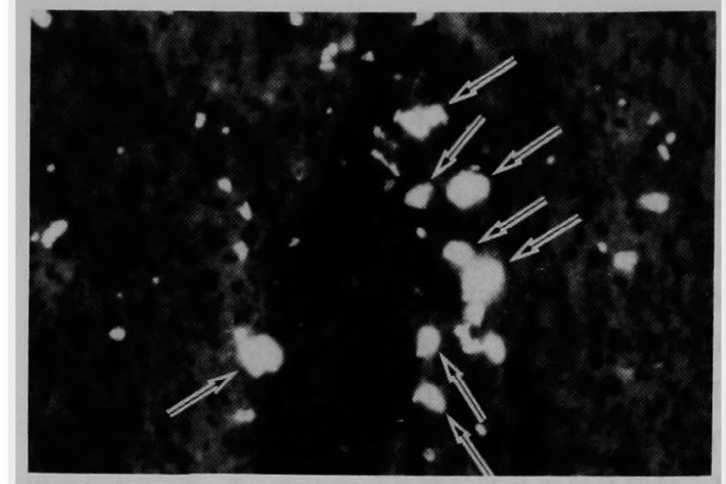

Fig. 2a Immunoflorescent study of mononuclear cells in liver specimen of hepatitis mice with the use of anti-Ly 2 antibody. The arrows indicate Ly $2^{+}$cells.

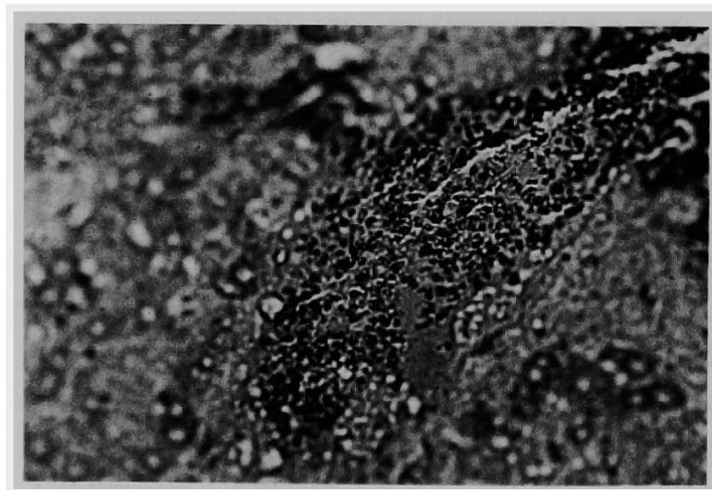

Fig. 2b Immunoperoxidase study of mononuclear cells in liver specimen of hepatitis mice with the use of anti-Ly 2 antibody. Ly $2^{+}$cells are found around the periportal area and in the parenchyma.

た.

一方 Bartholomaues らは，マウスを用いた実験系 で, 抗 LSP 抗体などの液性抗体が血中に十分に存在す る状態においても，肝障害が全くみられないことから， 抗肝細胞膜抗体のみでは肝障害を惹起できないのでは ないかと報告している ${ }^{18)}$ 。さらに Scheiffarthらはマ ウスに発症させた実験肝炎において単核細胞の果たす 役割について報告しており ${ }^{19.20)}$, 肝細胞障害の発症に おける細胞性免疫の重要性が検討されている。

筆者ら近交系B6マウスに同系肝抗原及び Freund's complete adjuvant を免疫することにより門 脈域に単核球浸潤を伴う肝炎モデルの作製に成功 し8)，その細胞性免疫につき検討を試みた。 
この訮炎モデルの脾細胞 NWC non-adherent 分画 (T-cell enriched) が syngeneic な LSP に対して強い 反応性を示すことは，本実験に括いて細胞性免疫機構 が作動し, 肝障害の発症にT-cell が何らかの役割を果 たしていることを示唆して拐りこの事については既 に報告を行なってきた ${ }^{8 \sim 10)}$. この点をさらに追求する ために，正常及び肝资マウスの末梢血，脾及び肝より 単核細胞を分離し，特異的抗体を用いて T-cell の比率 及び T-cell subpopulation につき検討した。マウスの T-cell は細胞表面に存在する特異的分化抗原である Ly 抗原系により亜分類されており，Ly 抗原系の表現 型と機能との関係が種々の実験系を用いて研究されて いる13,14). Ly 1は helper/inducer T-cell あるいは遅延 型アレルギーの effector cell と言われ，Ly 23 は cytotoxic/suppressor T-cell と考えられている.

末梢血単核細胞中の T-cell の比率は肝资マウスと 正常マウスで特に著しい差はみられないが， subpopulationをみると，肝资マウスでLy 1陽性及び Ly 23陽性細胞が著明に增加している。

脾細胞では NWC adherent 分画で T-cell の占める 比率が肝炎マゥスで有意に増加しており， subpopulation でも 分画前及び NWC adherent 分画において Ly 23の比率が高くなっている．著者らの肝炎モデルを用 いた実験系で，肝炎マウス脾細胞を正常マウスに transferすることにより類似の病変を作製できるこ と9)，及び正常 B6マウスの分離肝細胞を標的細胞とし た. in vitroの assay 系で, 肝资マウス脾細胞, 中です NWC adherent 分画中の T-cell が細胞障害性を示す こど0)はすでに報告したが，T-cell subpopulation 分 布の变化 (Ly 23の増加) が肝障害若起能力と関連して いる可能性があると思われる。

肝内浸潤勫胞の解析には, 肝組織よりリンハ球を単 離して行なら方法と, 凍結切片に䖝光ないし䣼素抗体 法を用い， in situにて分析する方法があるか，筆者ら は前者を用いて数量的解析を行い，後者でリンバ球の 分布について検討した. その結果, 肝内浸潤細胞中 T. cell は32.7\%，5ち約40\%が Ly 23陽性であり, NWC adherent 分画では42\%を Ly 23陽性細胞が占めた。䖝 光抗体法及ひ醅素抗体法による in situの分析では， Ly 1陽性細胞と Ly 2陽性細胞との間に特に明らかな 分布の差はみられなかった。 monoclonal 抗体を用い た肝内漫潤細胞の分析は種々のヒト肝疾患で行なわれ ておりィー8), リンバ球単離法です in situ分析法です $\mathrm{T}$ cell が漫潤細胞の主体であるとする報告が多い。さら
K piecemeal necrosis や実質内壊死部では，OKT 8 (suppressor/cytotoxic) 陽性細胞が多数を占めるとい われている. 表面抗原からは cytotoxic と suppressor T-cell の区別はできないがこれら浸潤細胞は cytotoxic T-cell と考えられ, 肝細胞障害の機序とし て T-cell mediated cytotoxicity が注目されている.

一方 antoimmune hepatitisでは，壊死部に plasma cell $\ngtr \mathrm{OKM}_{1}, \mathrm{OKM}_{2}$ (単球, 顆粒球ないし NK cell) も存在し, 門脈域内漫潤細胞中 OKT 4 (helper/inducer)/OKT 8 比が大きいなどの特徵があり，T-cell mediated cytotoxicity 以外の機序例えば ADCC mechanismの関与している可能性も推測 (6)れている.

筆者らの肝炎モデルにおいて浸潤T細胞中 Ly 23 細 胞の占める割合がかなり高く, T-cell mediated cytotoxicity $か$ ，肝障害発症に重要な役割を果たして いる可能性が考えられる.しかしながら Ly 1 細胞の占 める割合も高く，T-cell 以外の浸潤細胞も多いため， 肝障害の発症には種々の細胞が複雑に関与していると 思われる。これら細胞間の相互作用の解析及び機能面 まで含めた検討が，肝障害発症機序の解明に不可欠と 思われた。

\section{結語}

近交系 C57BL/6（B6） マウスに同系肝抗原及びァ ジェバントを免疫することにより，実験肝炎モデルを 作製し，その細胞性免疫機構につき検討を加えた。

その結果, 肝炎マウス末梢血単核細胞及び脾細胞 $\mathrm{T}$. cell かi syngeneic な LSP に対して反応性を示し，その T-cell subpopulation 正常マウスと比較して著しい 変化がみられた。 また肝内浸潤細胞ではT-cell が $32.7 \%$ 占め, この内 Ly 23 (cytotoxic/suppressor) 細胞は約40\%であった，螢光抗体及び酵素抗体法によ る in situ の分析では，肝組織の門脈域を中心に Ly 23 陽性細胞が認められ，Ly 1陽性細胞もみられた。これ らの結果より肝障害発生に cell-mecliated cytotoxicity が関与している可能性が推測され，さらにLy $1 及$ び Ly 23陽性細胞間の相互作用も含めた今後の検討が 必要と思われた。

\section{女解}

1) Thomson AD, Cochrane AMG, McFarlane IG, et al: Lymphocyte cytotoxicity to isolated hepatocyte in chronic active hepatitis. Nature 252 : 721-722, 1974

2) Kakumu S, Hara T, Goji $T$, et al : Lymphocyte cytotoxicity against Chang liver 
cells in chronic active hepatitis. Cell Immunol $36: 46-53,1978$

3) Kawanishi $\mathrm{H}$ : Morphological association with hepatocytes in chronic liver disease. Arch Pathol Lab Med 101 : 286-290, 1970

4) Colucci G, Colombo M, Del Ninno E, et al: In situ characterization by monoclonal antibodies of mononuclear cell infiltrate in chronic active hepatitis. Gastroenterology 85: 1138-1145, 1983

5) Pape GR, Rieber EP, Eisenberg J, et al : Involvement of the cytotoxic/suppressor T-cell subset in liver tissure injury of patients with acute and chronic liver disease. Gastroenterology $85: 657-662,1983$

6) Eggnik HF, Houthoff $\mathrm{HJ}$, Huitema $\mathrm{S}$, et al : Cellular and humoral immune reactions in chronic active liver disease. I lymphocyte sub. sets in liver biopsies of patients with untreated idiopathic autoimmune hepatitis, chronic active hepatitis B and primary biliary cirrhosis. Clin Exp Immunol 50 : 17-24, 1982

7) Mariani E, Facchini A, Miglio F, et al : Analysis with OKT monoclonal antibodies of $T$. lymphocyte subsets present in blood and liver of patients with chronic active hepatitis. Liver 4: 22-28, 1984

8) Mori Y, Mori T, Yoshida H, et al: Study of cellular immunity in experimental hepatitis in mice. Clin Exp Immunol 57 : 85-92, 1984

9) Mori Y, Mori $T$, Ueda $S$, et al: Study of cellular immunity in experimental autoimmune hepatitis in mice - Transfer of spleen cells sensitized with liver proteins-. Clin Exp Immunol $61: 577-584,1985$

10) Mori T, Mori $Y$, Yoshida $H$, et al: Cellmediated cytotoxicity of sensitized spleen cells against target liver cells - In vivo and in vitro study with a mouse model of experimental autoimmune hepatitis-. Hepatology 5: 770 $-777,1985$

11) MacFarlane IG, Wojcicka BM, Zucker GM, et al: Purification and characterization of human liver specific membrane lipoprotein (LSP). Clin Exp Immunol 27 : 381-390, 1977

12) Chan EL, Mitchell GF, Mishell RI: Cell interaction in an immune response in vitro : Requirement for theta-carrying cells. Science $170: 1215$ $-1217,1970$

13) Cantor H, Boyse EA: Functional subclasses of $T$ lymphocytes bearing different ly antigens. I the generation of functional distinct $T$-cell subclass is a differenciated process independent of antigen. J Exp Med 141 : 1376-1389, 1975

14) Cantor H, Boyse EA : Functional subclasses of $\mathrm{T}$ lymphocytes bearing different ly antigens. II cooperation between subclasses of $\mathrm{Ly}^{+}$cells in the generation of killer activity. J Exp Med 141 : 1390-1398, 1975

15) Meyer zum Büschenfelde $\mathrm{KH}$, Kössling $\mathrm{FK}$, Miescher PA, et al: Experimental chronic hepatitis in rabbits following immunization with human liver proteins. Clin Exp Immunol 11 : 99-108, 1972

16) Hopf U, Meyer zum Büschenfelde $\mathrm{KH}$, Freudenberg $\mathrm{J}$ : Liver specific antigens of different species. II localization of a membrane antigen at a cell surface of isolated he patocytes. Clin Exp Med 16: 117-124, 1974

17) Jensen DN, MacFarlane IG, Dortmann BS, et al: Detection of antibodies against a liver specific menbrane lipoprotein in acute and chronic hepatitis. N Eng J Med 299 : 1-7, 1978

18) Bartholomaues WN, Reed WD, Joske RA, et al : Autoantibody response to liver specific lipoprotein in mice. Immunology $43: 219-236$, 1981

19) Scheiffarth, Warnatz H, Mayer $K$, et al : Studies concerning the improtance of mononu. clear cells in the development of experimental hepatitis. J Immunol 98 : 396-401, 1967

20) Warnatz H, Scheiffarth F, Schmeissner R, et al: Studies on the cytotoxic effect of in vivo and in vitro immunized lymphocytes on liver target cells. Clin Exp Immunol 21 : 250-258, 1975 


\title{
Study of subpopulations of infiltrating cells in the liver with experimentally induced hepatitis in mice
}

\author{
Makoto OGAWA, Yoshio MORI, Teruo MORI, Shiro UEDA, Hiromichi YoshIDA, \\ Isao KATo, Kenji IESATO, Yoko WaKaSHIN, Masafumi WAKASHIN \\ and Kunio OKUDA*
}

This study has been performed based on our model of experimental hepatitis prodused by immunizing C56BL/6 (B6) mice with syngeneic liver proteins and Freund's complete adjuvant. Peripheral blood lymphocytes (PBL), spleen cells and infiltrating cells in liver were obtained from hepatitis mice, and they were subjected to $T$-cell subpopulation analysis using specific antibodies; the reactivity of these cells to LSP was also studied by the lymphocyte transformation test. In this study, PBL and the T-cell fraction of spleen cells of hepatitis mice showed a high reactivity to syngeneic LSP. The population of T-cells checked by anti-Thy 1,2 antibody was $32.7 \%$ in infiltrating cells in the liver of hepatitis mice and about $40 \%$ of this infiltrating T-cells were Ly 23 positive T-cell subpopulation (suppressor/cytotoxic). Ly 23 positive T-cell subpopulation was increased in the spleen of hepatitis mice compared to normal mice.

By indirect immunofluorescent and immunoperoxidase study, Ly 23 positive T-cells were found around the periportal area and in the parenchyma of hepatitis mice.

* The First Department of Medicine, Chiba University School of Medicine (Chiba) 